\title{
SYNERGIZED NETWORK ASSET: A DRIVER FOR INDONESIA'S FURNITURE INDUSTRIES TO ELEVATE MARKETING PERFORMANCE
}

\author{
Ahmad Ikhwan Setiawan* \\ Universitas Sebelas Maret, Indonesia \\ Augusty Tae Ferdinand \\ Universitas Diponegoro, Indonesia
}

\begin{abstract}
The main focus of this study is developing synergized network asset as a mediator variable for improving marketing performance. The research model was tested using AMOS SEM on 280 local market-oriented furniture makers. The output of the statistical analysis confirms that two buffer variables, namely relational capability and market dynamic adaptability, sustain synergized network asset and marketing performance. However, synergized network asset does not play a strong mediation role in increasing marketing performance. The slow-growing furniture industry is in greater need of responsive rather than synergistic cooperation. The concept of synergized network asset, which is characterized by the sustainability of collaboration quality, contributes to the development of business network theory as one of the main factors in marketing relationships.
\end{abstract}

Keywords: Synergized Network Asset, Relational Capability, Market Dynamic Adaptability, Marketing Performance.

Received: 19 July 2019

Accepted: 31 December 2020

https://doi.org/10.33736/ijbs.3758.2021

\section{INTRODUCTION}

Companies should facilitate themselves with various marketing strategies in order to deal with increasingly fierce business competition as well as to sustain business continuity. Companies must strive not only to obtain the advantages of price and product quality, but also to communicate proactively with customers, which in this context can be viewed as the relationships between supplier and buyer, buyer and seller, manufacturer and retailer, and company and end-user (Izquierdo \& Cillian, 2004; Landeros et al., 1995). Companies should deliver to their customers a competitive product and an excellent service (Jambulingan et al., 2011; Jones et al., 2008). Each company competes to provide the best service for its customers, and is aware that retaining its current customers is better and more effective than attempting to obtain new ones (Kracklauer et al., 2001). Nevertheless, not all companies manage to gain the attention of their customers; only companies that are able to understand and fulfill their customers' needs can succeed in improving

\footnotetext{
* Corresponding author: Management Department, Faculty of Economics and Business, Universitas Sebelas Maret, Surakarta, Indonesia; Email: aikhwansse@gmail.com
} 
their marketing performance. In order to customize the needs of the customer properly, companies should identify the characteristics of each market segment in detail.

\subsection{Conceptual background}

Relational capability is a major activity in establishing business with customers. Companies must continue to develop a wide range of relationship skills in order to satisfy their customers (Ngungi et al., 2010). Relational capability serves as an important entry point in business relationships and enables companies to improve their business relationships (Smirnova et al., 2011). Conversely, if a company's relational capability does not fulfill the necessary business requirements, it is difficult for the company to achieve its best performance (Brown et al., 2016). In establishing business relationships with new customers, relational capability helps maintain the continuity of business with existing customers. In a growing a company, a higher level of relational capability is required for the company to maintain its services to all customers. In fact, many large companies set up a special division to provide optimal service to their customers, such as a customer service department, customer care unit, or other kind of customer complaint center.

Numerous existing studies have confirmed, with strong supporting arguments, the positive relationship between relational capability and marketing performance (Ling-yee \& Ogunmokun, 2001; Welbourne \& Val, 2009). Companies that have good relational capability are able to understand their customers' needs well, and this is evident in their product specifications, delivery services, and any additional product expediency, which leads to an increase in the level of product sales (Welbourne \& Val, 2009). Relational capability has the ability to maintain customer loyalty, which in turn has a direct impact on improving marketing performance (Lin et al., 2014). Companies that are able to communicate closely with customers and foster cross-functional cooperation with other companies have a strong potential to achieve their sales targets (Lado et al., 2011; Nielson, 1998; Smirnova et al., 2011). Companies that establish business relationships gradually form partnerships which lead to increasing sales. The more experienced companies are in establishing business relationships, the broader the market area that can be served.

The numerous researchers who emphasize the concept of sustainable cooperation differ in their opinions regarding the relationship between relational capability and marketing performance (Cheng et al., 2014; Welbourne \& Val, 2009). Some say that relational capability does not have the ability to improve marketing performance because it is merely a form of concrete cooperation between a company and its customers (Mention, 2013). The improvement of marketing performance is not only determined by relational capability but also by a company's ability to provide a competitive advantage for its business partners (Welbourne \& Val, 2009). This opinion does not necessarily ignore the importance of the role of relational capability in establishing interorganizational relationships but considers that relational capability in itself has no great impact on marketing performance. Relational capability requires other variables to bring about an improvement in marketing performance (Cheng et al., 2014).

Relational capability requires an intervening variable to affect marketing performance. Although relational capability is the basic ability of companies to connect with customers, companies also require other cooperation skills in order to further develop the close relationships that enable mutually beneficial collaborations (Brown et al., 2016; Mention, 2013; Nielson, 1998). This intervening variable has collaborative power which encourages equal partnership and mutual 
interest (Brown et al., 2016; Setiawan \& Hanfan, 2017; Turner et al., 2000). This variable is also binding which means that the two parties working together become mutually dependent (Lado et al., 2011). Synergized network asset is synthesized from various major theories and is considered to have the ability to act as an intervening variable that bridges relational capability and marketing performance. Synergized network asset is viewed as a solution to this contradiction.

\subsection{Indonesia's furniture industry dynamic}

The local market-oriented furniture industry in Indonesia has suffered a decline in the past decade due to its inability to withstand the tough competition that exists in the furniture business (Department of Trade and SMEs Industries, 2017). Between 2006 and 2016, the market demand for furniture decreased by an average of $5 \%$ per year (Statistics of Indonesia, 2017). The influx of a variety of relatively cheaper imported furniture products from other Asian countries means that consumers now perceive national furniture as being more expensive, and as a result the demand for local furniture has declined (Roda et al., 2007). Local furniture makers have experienced a rise in production costs due to the increasing prices of raw materials such as wood and oil, and also increased labor costs. Some furniture makers endeavor to overcome this problem reducing production costs by decreasing the quality of raw materials, combining wood with cheaper plastic materials, or developing attractive designs by minimizing the use of wood. These efforts by furniture makers need to be communicated to the buyers so that they will continue to cooperate in marketing the furniture produced.

Indonesian furniture makers who market their products according to the needs of domestic consumers or the local market have a number of unique characteristics. The characteristics of products for the domestic market are different from those intended for export or foreign consumers (Roda et al., 2007). Furniture for the domestic market tends to be smaller and carving designs are simpler, while furniture for the international market tends to be larger, more luxurious, and with more innovative carving designs. The quality of local products is designed to suit the middle and lower segments of the market and is therefore cheaper than export-oriented products. The export market usually demands products of premium quality in accordance with the requirements of the country of destination. Furniture makers continue their businesses from generation to generation, the skills and experience of making furniture being passed down from parents to children and grandchildren. These businesses are found in certain areas of furniture producing cities such as Jepara, Surakarta and Cirebon where industrial clusters are formed with furniture makers working together both in the procurement of materials and production.

In order to study in greater depth the role of synergized network asset extracted from the contradictive views on relational capability and marketing performance, this research reviews various basic theories to ascertain the historical emergence of this concept. The empirical research model is then developed by constructing the antecedent variables of synergized network asset and marketing performance. The proposed model is confirmed by means of statistical testing of primary data. In the final chapter, the research discusses the statistical results, conclusion, managerial implications, and recommendations for future research development. 


\section{LITERATURE STUDY AND RESEARCH MODEL DEVELOPMENT}

\subsection{Synergized network asset}

The concept of synergized network asset is derived from two general relationship theories, namely relationship marketing and social capital. Relationship marketing, which is founded on resource dependence theory and social exchange theory, emphasizes the importance of relationships between internal and external parties of a company so that business can thrive well (Eiriz \& Wilson, 2004; Gronroos, 1994). While highlighting the importance of a social capital network, companies should also form a strong business cooperation network (Burt, 1992). Companies should optimize internal assets by collaborating with external strategic resources.

Relationship marketing, as the parent theory, deploys the concept of inter-organizational relationships (Gronroos, 1994; Landeros et al., 1995). It discusses the factors that encourage cooperation between organizations, and is concerned with ways to maintain cooperation and improve the positive effects of cooperation. Some of the dimensions of this concept are related to knowledge sharing and collaborative activities that emphasize openness and willingness to engage in joint use of assets (Eiriz \& Wilson, 2004; Nielson, 1998). Relations between organizations require a dimension of mutual benefit in order for mutual cooperation and reciprocity collaboration to be indispensable (Kracklauer et al., 2001; Tsanos et al., 2014). Cooperation will be effective and sustainable if each party encourages synergy. Studies have explored at great length synergy as a dimension of relationships between organizations to boost the output of cooperation (Connell \& Voola, 2007). Synergistic relationships require each party to develop solution-based relationships in solving problems (Jambulingam et al., 2011).

Social capital theory explains a company's motivation to establish cooperation with other companies in a more complex fabric (Burt, 1992). Social capital forms networks among organizations which create closer relationships of cooperation (Krackhardt, 1993) As business developments continue to grow, the study of business networking has gained increasing attention (Batonda \& Perry, 2003). In order to sustain the continuity of cooperation, every relationship requires various assets which enhance the bonds of business networking, such as network competence (Claro \& Claro, 2011), network capacity (Cambra-Fierro, Florin, Perez, \& Whitelock, 2011), network solidity (An et al., 2014) and pareto sales network asset (Ferdinand \& Killa, 2018). The development of a networking concept also becomes more strategic in the context of cooperation between organizations, and this has led to more dynamic studies such as the ones known as network collaboration (Westerlund \& Rajala, 2010) and collaboration in network (Claro \& Claro, 2011).

Synergized network asset is a form of collaborative cooperation that is highly responsive to the customer. Synergized network asset is characterized by joint problem solving, sustaining relationship continuity, ensuring product availability, strengthening competitive position, and commitment to cooperation (Lado et al., 2011; Lin, Tsai \& Chiu, 2009; Tsanos et al., 2014). Synergized network asset treats collaboration as a basis for planning and implementing marketing strategies. Through synergized network asset, a company, together with its network partners, anticipates and circumvents competitors' endeavors that may disrupt business relationships (Batonda \& Perry, 2003). The real shape of synergized network asset is a marketing program that is fully supported by all business partners. 
There are various models of company-customer cooperation for increasing performance. Nurcholis (2012) developed a model of cooperation, known as an equilateral relationship, to coordinate business among the different components in the supply chain of an automotive company. Performance can be achieved in a supply chain if there are policies with common dependency, common transparency, and common standardization. Hartono (2013) revitalized the concept of cooperation in the customer management relationship (Kracklauer et al., 2001), referring to it as a harmonious collaboration which enforces the ability or commitment of all parties to cooperate in order to improve the quality of the relationship. Performance can be achieved in a collaboration if both sides have the willingness to work together, share information and knowledge, solve problems quickly, and develop new ideas. Nabhan (2012) developed a model for the capability of cooperation, known as dynamic collaboration capability, to direct the learning process in achieving performance in collaboration and innovation. Various studies show that a cooperation model requires norms of equality which include the values of understanding, solidarity, interdependence, and conformity (Batonda \& Perry, 2003; Izquierdo \& Cillian, 2004; Jambulingam et al., 2011). Therefore, the cooperation model known as synergized network asset has the same spirit, to support companies in building and enhancing their success in marketing performance, as well as carrying out the functions of promotion, distribution of goods, and maintenance of relationships with consumers (Ling-yee \& Ogunmokun, 2001; Smirnova et al., 2011).

\subsection{Synergized network asset and marketing performance}

Partnerships that are based on an understanding of mutual support and development will affect business performance (Fynes \& Voss, 2002). The ability of both parties to adjust to each other and to strengthen each other's conditions makes them more competitive (Izquierdo \& Cillian, 2004). The communication skills of both parties in coordinating and delivering information interactively enables them to avoid disputes and reduces dysfunctional conflict. Good partnerships will improve various aspects of a company's performance, including customer satisfaction, innovation, market effectiveness, and market efficiency.

The collaboration between a company and its customers affects company performance. Companies that cooperate with customers more easily develop cooperative relationships, enabling the company to increase its product sales (Ferdinand \& Killa, 2018). Likewise, customers who are able to work closely with suppliers will gain a better supply of goods, which enables them to improve marketing performance (Santra, 2018). Liu et al. (2013) shows that collaboration between companies leads to better company performance, including aspects such as on-time delivery, delivery according to demand, suitability of product quality, and services that meet the customer's expectations. The characteristics of a company that collaborates successfully with its partners include the ability to adapt and respond quickly to change, quality of support to solve problems, ability to create innovative policies, and expectation of sustainable linkages (Corsten \& Felde, 2005; Ensign, 1998; Prior, 2012). The value of these characteristics should improve company performance.

Synergistic relationships greatly affect the outcome of cooperation (Corsten \& Felde, 2005). Ensign (1998) shows that synergistic relationships between a company and its customers support the efforts of both to achieve improvement in the performance of the company. In addition to reducing operating costs, synergistic relationships also improve cost efficiency, thus ultimately improving profitability. In turn, this increases marketing efforts through increased cooperation and 
joint sales promotions that sell products directly to the end consumer (Setiawan \& Hanfan, 2017). Companies that are able to obtain the additional benefits of synergy, such as increasing sales, access to low-cost input, and cost efficiency, are able to achieve supply chain performance as measured by supply speed, delivery reliability, and product flow flexibility (Claro \& Claro, 2011). The benefit of a collaborative relationship is to create a synergy value that encourages the achievement of sustainable business performance.

A marketing department will be successful in performing its duties if the quantity of goods and services that the consumer uses is seen to increase. Certainly, indicators of marketing performance are completely different from performance indicators in other departments, for example in operation activities (Tsanos et al., 2014), resources management, and finance (Mention, 2013). Nevertheless, studies that define business performance as an output model frequently assign certain indicators of marketing performance as a part of business performance, aligning them with indicators from other departments, such as productivity, innovation, and profitability (Claro \& Claro, 2011; Lado et al., 2011; Liu et al., 2013).

Network synergy uses relational benefit to achieve competitive advantages (Siguaw et al., 1998). Network expediencies, such as synergy of production, synergy of resources, and synergy of marketing efforts, support companies in achieving marketing performance. Support from networking partners in improving the quality of production helps a company to reach its sales target, which is evident by looking at how much money the company has obtained, or to achieve a greater market share, as shown by the number of areas a company has reached (Nielson, 1998; Smirnova et al., 2011). The synergy between a company's resources and its networking partners improves operational cost efficiency (Prior, 2012). Likewise, Setiawan and Hanfan (2017) state that the participation of network partners in the marketing program accelerates the achievement of sales growth and market share. Based on this idea, the following hypothesis can be proposed:

\section{$\boldsymbol{H}_{1}$ : Synergized network asset positively influences marketing performance.}

\subsection{Relational capability and synergized network asset}

Relational capability, which develops from active relational behavior, encourages companies to optimize their ability to relate to the environment (Canning \& Hanmer-Lloyd, 2001; Ngungi et al., 2010). Companies should always maintain their business vision and mission in order to lever valuable relationships (Landeros et al., 1995). Relational capability is not only due to a company's capacity of resource management, including production capacity, technological capability, and flexibility of the company's resources, but is also boosted by the company's efforts to adapt to its environment (Ling-yee \& Ogunmokun, 2001). A company is willing to adapt to its partners if it understands the importance of cooperation with other companies. Relational strength in business networks is determined by the willingness of each partner to interact and synergize (Connell \& Voola, 2007).

Relational capability is defined as the ability of a company to use its internal resources to establish relationships with other companies so that it obtains relational benefits (Ngungi et al., 2010; Smirnova et al., 2011). Relational capability is constructed by a variety of constructive behaviors that support cooperation sustainability, such as the ability to establish trust (Ambrose et al., 2010) and maintain a committed relationship (Ling-yee \& Ogunmokun, 2001; Morgan \& Hunt, 1994). 
Relational capability can also be developed through the personal strengths and integrity of each company owner or manager, which includes characteristics such as honesty, openness, fairness, and the ability to form close relationships (Batonda \& Perry, 2003; Nielson, 1998).

A company's ability to understand its business partners improves the quality of its network (Claro \& Claro, 2011; Westerlund \& Rajala, 2010). Relationships based on equality encourage companies to pay attention to their business partners (Jambulingam et al., 2011). If a company understands its customer's needs, it will enhance the intimacy needed to cooperate. The various characteristics of customers that a company needs to know include convenience of communication media, time of visits, financial strength, product variations required, and end-user segments served (Setiawan \& Hanfan, 2017). Companies that understand their customers' desires are able to gain the trust and confidence of their business partners so that they can discuss opportunities and challenges for future business (Izquierdo \& Cillian, 2004).

The ability to provide a platform for relationships supports sustainable cooperation. A platform that communicates clearly with the partner determines the quality of cooperation (Connell \& Voola, 2007; Lin et al., 2014; Nielson, 1998). Companies should be able to convey the advantages of their products or services in order to gain the confidence of business partners (Setiawan \& Hanfan, 2017). Various competitive advantages can be conveyed, including low cost, product quality, and supply sustainability. If a company appoints sales staff to represent the company, it is essential that they have good product knowledge, communication skills, and a high level of personal honesty (McDowell \& Harris, 2009). Experienced sales staff will be able to convince the customer to respond to the company's marketing programs and thus increase the level of sales. Conversely, if the company's ability to communicate with its business partners decreases, it will be difficult for the company to continue prospective cooperation endeavors.

The quality of close relationships affects the efforts of business interactions. Companies that are able to establish close relationships with business partners through personal activities will find it easier to build cooperation (Batonda \& Perry, 2003; Nupus \& Ichwanudin, 2020). Some theorists say that close relationships are the result of mutual trust, while others are of the opinion that it is the close relationships existing between two parties that make them more trusting (Nielson, 1998). Nonetheless, researchers agree that closeness and trust form a psychological environment which encourages intensity of cooperation (Izquierdo \& Cillian, 2004). In a relationship with mutual trust, both parties will be willing to bear risks and seek joint solutions in order to ensure continuity in the business.

Companies should be able to attract prospective partners to form collaborations. If a company has a good reputation, it will motivate partners to establish relationships (Welbourne \& Val, 2009). Companies should always position the customer as the important party, and for this reason, every complaint made by a customer should be resolved wholeheartedly. Companies can share positive information with potential customers who have similar strategies in looking to form relationships. The ability to enhance relational advantages cannot be achieved instantly since a number of stages must first be passed through, such as promotion, introduction, and verification (Smirnova et al., 2011). In order to support the other parties involved in the collaboration, each of these stages must be managed effectively.

Relational capability is essential for forming network synergy. Manufacturers that have the ability to maintain good relationships and convince their partners of real advantages such as product 
quality, supply continuity, and competitive prices, collaborate successfully with their partners (Izquierdo \& Cillian, 2004). If they are able to build trust in business, the decision-making coordination in marketing and distribution activities are repeatedly arranged to respond to business opportunities and challenges (Ensign, 1998). In addition, cooperation activities in the form of joint forecasting should to be carried out continuously. Liu et al. (2013) stresses that the closeness of a relationship, which is characterized by an impressive personal network, improves synergy in the form of information and knowledge sharing. This thought gives rise to the following hypotheses:

\section{$\boldsymbol{H}_{2}$ : Relational capability positively influences synergized network asset.}

\subsection{Market dynamic adaptability and synergized network asset}

Market dynamic adaptability, which is derived from the concept of dynamic capability, reflects a company's ability to respond to changes in dynamic in the business environment (Hallen et al., 1991; Teece et al., 1997). The way a company responds to its customers is an indication of the attention it awards its partners. A company should regard its partners as the valuable party and endeavor to satisfy their decisions. The willingness of a company to change or adjust its competition strategy will ensure that its customers continue to do business with the company. Although the company is already in a close relationship with its partners, it should still pay attention to and be aware of competitors' actions (Jones et al., 2008). If necessary the company can launch a counter attack on the policies of its competitors that are deemed to be interfering with its market share.

Market dynamic adaptability is measured by the speed and accuracy of a company's marketing strategy in responding to its competitors' actions (Siguaw et al., 1998). A company should not underestimate any of its competitors' changes in strategy that are designed to increase market share and profit because this will have a direct influence on the company (Baker \& Sinkula, 1999). The important thing for the company is to anticipate and respond immediately to any changes in its competitors' strategies. The faster a company's response to market expectation, the greater the company's efforts to collaborate with customers. Companies should realize that the speed of their response to their partners has an impact on market protection. Market dynamic adaptability can be judged by the degree of accuracy in the company's response to a competitor, and by looking at how the company's response may actually cause financial loss for its competitor because of a decrease in market share.

Cooperation that is a prerequisite to adaptability in a company's actions is largely determined by the conformity of characteristics between two parties (Canning \& Hanmer-Lloyd, 2001; Hallen et al., 1991). Cooperation is not based on the shape, size, or business experience of an organization but determined more by the common desire to achieve mutual benefit (Jambulingam et al., 2011). In addition, the different conditions between a company and customer actually create conditions that are needed by both parties. The company or supplier is looking for partners who can distribute a variety of products while the customer or retailer is looking for a company that is able to fulfill its retail needs. Therefore, the cooperation between company and customer is not determined by a common visible characteristic such as the shape and size of the company; instead, it depends on invisible characteristics such as purpose and commitment. The company's attention to the consumer should increase the quality of cooperation (Jones et al., 2008), and the company must 
continue to strive to determine the true characteristics and behavior of the consumer (CambraFierro et al., 2011).

The accuracy of a company's response to the customer affects the quality of the partnership (Canning \& Hanmer-Lloyd, 2001). The accuracy of the strategy for adapting to the market affects the company's effort to obtain new network partners as well as retaining its current network partners (Brennan et al., 2003). The company's competition strategy helps bring about significant results for the customers if they are also willing to support its implementation. Jones et al. (2008) shows that the competitive response of a company should be in accordance with the demand characteristics of the customers (retailers) and their end users. A company's promotional activities, such as rebates on a specific purchase order, may be offered to attract retailers which the demand of the end user for the particular product increases or shows a tendency to rise. Customers are willing to increase the supply of products in the hope of increasing their own profits. They are also willing to make additional orders for products that are considered cheaper in order to boost sales revenue. Therefore, companies need to establish communication with customers regarding the appropriate strategies for responding to complaints from networking partners. Based on this idea, the following hypothesis can be proposed:

\section{$\boldsymbol{H}_{3}$ : Market dynamic adaptability positively influences synergized network asset.}

\subsection{Market dynamic adaptability and marketing performance}

A company that has a good understanding of its consumers will gain a positive response from the consumers, which in turn helps the company to evaluate and improve its marketing programs (Liu et al., 2013). The dynamics experienced by market trends are largely determined by the development of the social, economic, cultural, technological and natural environment (Teece et al., 1997). At certain times, companies should evaluate their marketing strategies in order to adapt to the changing market trends. Consumers pay attention to marketing programs by following promotional programs, buying more products, and increasing the variety of products purchased. Consumers who trust marketing programs are willing to engage in companies' promotional programs even though the program requires the consumer to buy the company's products in greater numbers (Izquierdo \& Cillian, 2004).

A company that is aware of the high intensity of competition in the market strives to serve its partners with a proper response. Various customer complaints are awarded a quick response and as a result, network partners are willing to improve the quality of relationships (Cambra-Fierro et al., 2011). Companies should strive to maintain relationships with customers through active communication (Smirnova et al., 2011). Information on the company's competitors can also be obtained through communication with customers. Customers are interested in discussing the climate of competition because it enables them to evaluate the level of attention and concern of the company regarding the condition of competitors and customer needs (Santra, 2018). Companies often send their marketing managers or customer service staff to meet customers directly in an effort to locate and determine the real problems that customers face. These various efforts help forge closer relationships with network partners and enable the company to provide solutions to problems more quickly. 
The speed of a company's response to consumer complaints strongly influences the consumer's motivation to continue consuming a product (Jones et al., 2008). Companies should recognize that consumer dissatisfaction is an obstacle in developing customer loyalty programs. Nielson (1998) stresses that companies should increase market adaptation by initiating communication with consumers who complain about the quality of products and services, as input for improving their marketing programs. Customers who are satisfied with the way in which companies handle complaints tend to attempt to re-use a company's products. Satisfied customers help to build an element of mouth to mouth promotion as they become a source of reference, and influence other consumers to be loyal in their use of company products. Maintenance of this segment of loyal customers should be treated seriously because they are a major force in the company's new product marketing. This supports the following hypothesis:

\section{H: Market dynamic adaptability positively influences marketing performance}

Figure 1: Empirical Research Model

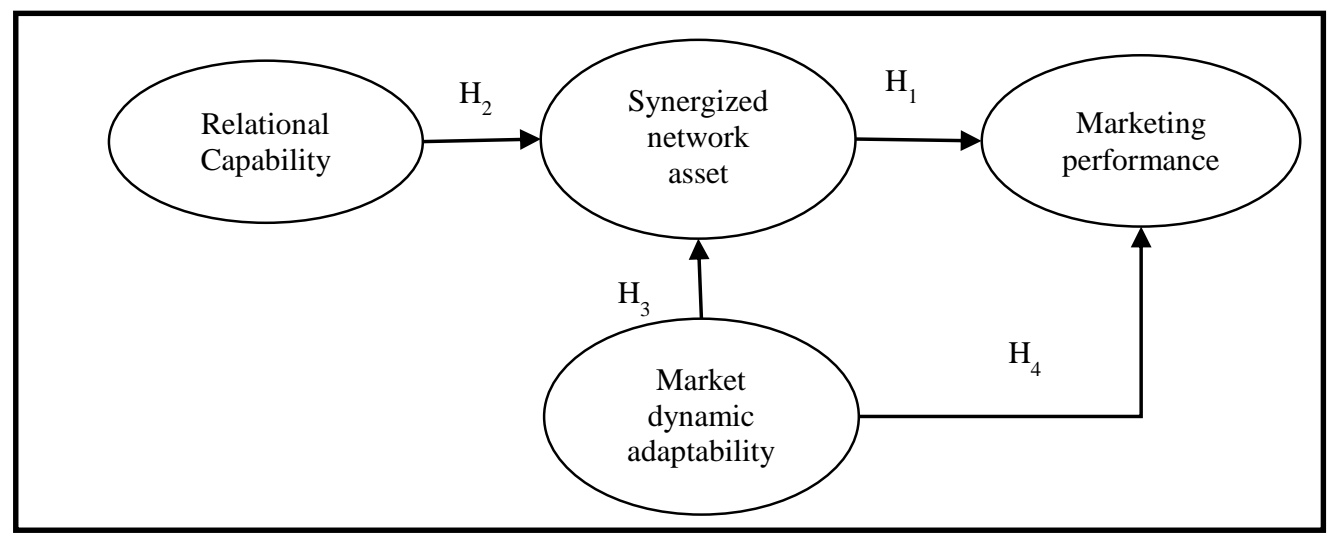

Various hypotheses based on previous research studies form an intact research model. This research model directs attention primarily towards synergized network asset, and subsequently determines the antecedent and consequent variables (Figure 1).

\section{RESEARCH METHOD}

\subsection{Data collection}

An empirical study was conducted on 280 of Indonesia's local market-oriented furniture producers in 2016-2017. There were initially approximately 4,100 furniture manufacturers identified in a number of different furniture industry centers across Indonesia. The research sample was narrowed down to 420 furniture makers dispersed throughout the towns of Jepara and Surakarta, where about $60 \%$ of all furniture makers in Indonesia are located. These two towns are also well known as centers of the furniture industry. These respondents, who are all registered in the State Ministry of Cooperatives and Small Medium Enterprises (Kemenkop UKM) and the Indonesian Furniture and 
Handicraft Industry Association (ASMINDO), were contacted directly and asked to fill out questionnaires that had been prepared. After verifying the questionnaires through a screening and trimming test, only 371 questionnaires were deemed eligible to be processed. The data also needed be normalized by removing the influence of outlier data and identifying a small value of Mahalanobis distance so that the data processing would meet the goodness of fit parameters required by AMOS. Data abnormalities make the parameters difficult to achieve and coefficients of relationship not eligible to be applied. It was found that 91 questionnaires had to be eliminated from the subsequent data processing. In the end, the data deemed fit to be processed was 280, of which 198 respondents were from Jepara and 82 from Surakarta.

The data normality value obtained by AMOS showed the level of normality to be eligible, with cr. skew and cr. kurtosis values of around $-2.548<$ normality value $<+2.548$. The preliminary data displayed symptoms of abnormality with some indicators of posse cr. skew and cr. kurtosis beyond those required (table 1). The multivariate normality also had a value that was out of range, at 15.723. A number of interventions were made to normalize the data, which were controlled so that each variable was within the normality interval required. These conditions resulted in a much better multivariate normality at -2.681 , close to the prerequisite value.

\subsection{Construct validity}

There are several latent variables for developing the research model which need to be explained by a number of indicators. Well-qualified indicators of variables can be identified by a number of validation tests, such as factor loading, AVE, and composite reliability with a cutoff value of 0.7. All of the indicators have a value of more than 0.7 except AVE of marketing performance, which has a marginal value of 0.676 (Table 1). However, the variable of marketing performance has a high value of composite reliability, at 0.862 and the variable can therefore still hold to proceed in subsequent analyses. Marketing performance can be measured by several related reflections, such as increase in sales value, improvement in sales volume, and achievement of significant additional sales growth (Ferdinand \& Killa, 2018; Ling-yee \& Ogunmokun, 2001; Smirnova et al., 2011).

Relational capability is measured by three major indicators, namely understanding of consumer characteristics, conviction of relationship benefits, and relationship closeness (Ling-yee \& Ogunmokun, 2001; Ngungi et al., 2010; Smirnova et al., 2011). The composite reliability of relational capability is 0.891 with the smallest value of the indicator's factor loading at 0.60. Market dynamic adaptability is measured by three indicators, namely market trend analysis, market adjustment, and speed of market adaptation, with a composite reliability of 0.792 (Siguaw et al., 1998; Teece et al., 1997). All the indicators of market dynamic adaptability have a factor loading above 0.7 . The marketing performance variable has good composite reliability, at 0.863 , which is supported by three indicators: sales value, sales volume and sales growth (Lin et al., 2014; Nielson, 1998; Smirnova et al., 2011). To be certain that a company is improving in its marketing performance and to avoid accidental events, the time frame of the research should take into account the number of years observed, which is between three and five years. These indicators provide a validity value in which factor loadings are greater than 0.7 . 
Table 1: Construct Validity

\begin{tabular}{|c|c|c|c|c|c|c|c|}
\hline \multirow{2}{*}{ Variables and indicators } & \multicolumn{2}{|c|}{ Before normalized } & \multicolumn{2}{|c|}{ After normalized } & \multirow{2}{*}{$\begin{array}{l}\text { Factor } \\
\text { loading }\end{array}$} & \multirow{2}{*}{ AVE } & \multirow{2}{*}{$\begin{array}{l}\text { Composite } \\
\text { reliability }\end{array}$} \\
\hline & $\begin{array}{c}\text { Cr. } \\
\text { skew }\end{array}$ & $\begin{array}{c}\text { Cr. } \\
\text { kurtosis }\end{array}$ & $\begin{array}{c}\text { Cr. } \\
\text { skew }\end{array}$ & $\begin{array}{c}\text { Cr. } \\
\text { kurtosis }\end{array}$ & & & \\
\hline Synergized network asset & & & & & & 0.706 & 0.906 \\
\hline - Joint problem solving & -1.146 & -2.131 & -0.396 & -2.149 & 0.845 & & \\
\hline $\begin{array}{l}\text { - Relationship continuity/ } \\
\text { sustainability }\end{array}$ & -0.945 & -1.89 & -0.879 & -1.261 & 0.863 & & \\
\hline $\begin{array}{l}\text { - Ensuring availability of } \\
\text { supplies }\end{array}$ & -6.298 & 0.834 & 0.129 & -2.241 & 0.836 & & \\
\hline - Cooperation commitment & -5.148 & 4.483 & -2.059 & -0.427 & 0.816 & & \\
\hline Relational capability & & & & & & 0.731 & 0.891 \\
\hline $\begin{array}{l}\text { - Understanding of } \\
\text { customer characteristics }\end{array}$ & -3.038 & 1.238 & -1.887 & -0.997 & 0.835 & & \\
\hline $\begin{array}{l}\text { - Conviction of } \\
\text { relationship benefits }\end{array}$ & -4.526 & -2.702 & -0.961 & -2.215 & 0.870 & & \\
\hline - Relationship closeness & -0.647 & 1.838 & -0.946 & 0.803 & 0.860 & & \\
\hline $\begin{array}{l}\text { Market dynamic } \\
\text { adaptability }\end{array}$ & & & & & & 0.707 & 0.879 \\
\hline - Market trend analysis & -4.121 & 5.143 & -2.190 & 0.782 & 0.838 & & \\
\hline $\begin{array}{l}\text { - Customer complaint } \\
\text { completion }\end{array}$ & -6.382 & 5.882 & -1.757 & 0.067 & 0.845 & & \\
\hline - Market adaptation & -4.358 & 2.496 & -1.607 & -0.105 & 0.837 & & \\
\hline Marketing performance & & & & & & 0.676 & 0.862 \\
\hline - Sales value & -4.053 & -1.37 & -1.378 & -0.652 & 0.821 & & \\
\hline - Sales volume & -4.08 & -0.906 & -1.621 & -2.419 & 0.814 & & \\
\hline - Sales growth & -5.226 & -0.041 & -0.291 & -0.907 & 0.831 & & \\
\hline Cr. Multivariate & 15.723 & & -2.681 & & & & \\
\hline
\end{tabular}

\subsection{Characteristics of respondents}

In general, 280 respondents who were able to proceed statistically had the ability to market their products (Table 2). The majority of furniture makers in the study were senior high school graduates (69\%), though some only studied to the level of junior high school because their families encouraged them to continue the family business rather than to get a higher education. A small number of respondents were university graduates with better knowledge of business analysis. The respondents have been in the furniture business for 10-15 years. Since the respondents were small and medium enterprise owners, not all of them had furniture display rooms as part of their marketing facilities. In fact, only $20 \%$ of them had this facility. Their target market focused on various cities in the province of Central Java (64\%), although a number of them had expanded their market area to other provinces (19\%) and to a national scale (17\%). The furniture makers who were able cover a larger market area tended to have more business experience and product display room facilities. 
Table 2: Characteristics of Respondents

\begin{tabular}{lrl}
\hline \hline Characteristics & Number \\
\hline Education level of company owner & 56 & $20 \%$ \\
Junior high school & 194 & $69 \%$ \\
Senior high school & 30 & $11 \%$ \\
University & & \\
Furniture business experience & 55 & $20 \%$ \\
Less than 10 years & 148 & $53 \%$ \\
10- 15 years & 77 & $28 \%$ \\
More than 15 years & & \\
Product display room & 56 & $20 \%$ \\
Available & 224 & $80 \%$ \\
Not available & & \\
Scope of market & 180 & $64 \%$ \\
Within province & 52 & $19 \%$ \\
Between provinces & 48 & $17 \%$ \\
National & & \\
\hline \hline
\end{tabular}

\section{DATA ANALYSIS}

\subsection{Structural model analysis}

The research model test through AMOS shows a high level of model feasibility (Table 3). The significance value of the model is 0.121 , which is greater than the required value of 0.005 . The chisquare value of the model is 73.010 , which indicates that the model can represent the respondents' perception. These facts are reinforced by several goodness of fit parameters contained in the model that have a value greater than 0.9 , such as AGFI $=0.937$, GFI $=0.959, \mathrm{TLI}=0.989$ and $\mathrm{CFI}=$ 0.991. This indicates a high level of compatibility between the empirical model and the hypothesized model. The model also satisfies the amount of data to be processed by AMOS, as shown by a Hoelter value of 318 , which is above the number of 280 samples.

A test of the model with an acceptance probability value of $10 \%$ produces a coefficient estimation that supports most of the relationships between two hypothesized variables (Table 3). The estimated regression coefficient between the synergy of the responsive network and marketing performance is 0.417 with a probability value of 0.000 . This coefficient value supports hypothesis 1 that there is a positive influence between synergized network asset and marketing performance. Furniture makers who are able to manage cooperation in synergy with furniture showrooms can improve marketing performance. Furniture suppliers who are willing to resolve business disputes with a furniture showroom in a comprehensive manner, and share mutual interests, gain the enthusiastic support of customers to continue their relationships. The impact of a company's efforts to improve the quality of its relationships with furniture showrooms has a number of parameters, which include increasing the number of customers and volume of furniture sales. This is consistent with the concept presented by Siguaw et al.(1998), Corsten and Felde (2005) and Prior (2012), namely that companies that always maintain a commitment to cooperation and do not try to acquire unilateral interest alone (opportunistic) will receive a positive response from business partners, and in turn they will respond with an increased intensity of interaction and expand the number of product purchases (Morgan et al., 2016). 
Table 3: Structural Model Test

\begin{tabular}{lllcccc}
\hline \multicolumn{2}{c}{ Variable Relationship } & $\begin{array}{c}\text { Standardized } \\
\text { regression }\end{array}$ & C.r & P value & $\begin{array}{c}\text { Hypothesis } \\
\text { results }\end{array}$ \\
\hline $\begin{array}{l}\text { Synergized network } \\
\text { asset }\end{array}$ & $\rightarrow$ & $\begin{array}{l}\text { Marketing } \\
\text { performance }\end{array}$ & 0,417 & 3,786 & 0,000 & $\mathrm{H}_{1}$ supported \\
$\begin{array}{l}\text { Relational } \\
\text { capability dynamic }\end{array}$ & $\rightarrow$ & $\begin{array}{l}\text { Synergized } \\
\text { network asset }\end{array}$ & 0,344 & 3,890 & 0,000 & $\mathrm{H}_{2}$ supported \\
$\begin{array}{l}\text { Market } \\
\text { adaptability }\end{array}$ & $\begin{array}{l}\text { Synergized } \\
\text { network asset }\end{array}$ & 0,491 & 5,297 & 0,000 & $\mathrm{H}_{3}$ supported \\
$\begin{array}{l}\text { Market dynamic } \\
\text { adaptability }\end{array}$ & $\rightarrow$ & $\begin{array}{l}\text { Marketing } \\
\text { performance }\end{array}$ & 0,399 & 3,605 & 0,000 & $\mathrm{H}_{4}$ supported \\
\hline \hline
\end{tabular}

The estimated regression coefficient between relational capability and synergized network asset is about 0.2344 with a probability value of 0.000 , indicating that the coefficient can be feasibly accepted. This result supports hypothesis 2 that there is a positive influence between relational capability and synergized network asset. Furniture makers who are able to understand the wants and needs of furniture showrooms have a greater opportunity to establish closer cooperation with their customers. Furniture makers' capability to convince furniture showrooms that the products sold to the showrooms offer competitive advantages, such as lower prices, quality assurance of products, and professional services, encourages companies to build an ongoing relationship. This result confirms the statements of Izquierdo and Cillian (2004) and Liu et al. (2013) that the more open and intimate the relationship between a company and its customers, the stronger the pull of the customer to interact more intensively. These positive conditions motivate the company to transfer its advantages to customers in the form of guaranteed product availability, protection of local markets, and priority delivery.

The significance parameters between variable relationships indicate the role of market dynamic adaptability for its consequence variables. The estimated coefficient of influence from market dynamic adaptability to synergized network asset is 0.491 with a probability value of 0.000 . This value supports hypothesis 3 that the higher the competency in market dynamic adaptability, the higher the synergized network asset will be. Furniture makers with market adaptation capacity can easily arrange mutual cooperation with furniture showrooms. This conclusion is consistent with comments of Canning and Hanmer-Lloyd (2001) and Jones et al. (2008), who state that it is important for a company to understand the market trends as well as to adjust its marketing strategies quickly in order to achieve sustainable cooperation. In addition, the estimated coefficient between market dynamic adaptability and marketing performance is 0.399 , with a probability value of 0.000. These results support hypothesis 4 that competency in market adaptation greatly affects marketing performance. Furniture makers who are able to respond to market changes gain the power to intervene and expand market share (Smirnova et al., 2011). Cambra-Fierro et al. (2011) and Liu et al. (2013) also support these results, stating that companies can survive in fierce competition if they possess the dynamic capability to sense and analyze market trends, and adjust their internal company policies to suit the changing business environment.

\subsection{Mediating role analysis}

The analysis of effectiveness of a pathway can be discovered by paying attention to the intermediation effect value obtained by multiplying the direct effect values of the series of 
pathways through which it passes. Referring to the results of the structural model test (Table 4), there are three pathways that can be chosen to achieve marketing performance (MP). These can be arranged according to the intermediation effect values, as follows: 1) market dynamic adaptability $(\mathrm{MDA}) \rightarrow \mathrm{MP}, 2$ ) MDA $\rightarrow$ synergized network asset (SNA) $\rightarrow$ MP and 3) relational capability $(\mathrm{RC}) \rightarrow$ SNA $\rightarrow$ MP with the respective intermediation effect values of $0.399,0.205$ and 0.143 . The two pathways that pass through synergized network asset are seen to have lower intermediation effect values than the other pathway that does not pass through it. This indicates that synergized network asset does not play a significantly strong role as a mediator between market dynamic adaptability and marketing performance.

Table 4: Intermediation Effect to Improve Marketing Performance

\begin{tabular}{|c|c|c|c|c|c|c|c|c|}
\hline \multirow{2}{*}{ No } & \multirow{2}{*}{\multicolumn{5}{|c|}{ Pathway to improve marketing performance }} & \multicolumn{2}{|c|}{ Direct effect value } & \multirow{2}{*}{$\begin{array}{c}\begin{array}{c}\text { Intermediation } \\
\text { effect }\end{array} \\
\end{array}$} \\
\hline & & & & & & 1 & 2 & \\
\hline 1 & MDA & $\begin{array}{l}\rightarrow \\
(1)\end{array}$ & MP & & & 0.399 & & 0.399 \\
\hline 2 & MDA & $\overrightarrow{(1)}$ & SNA & $\begin{array}{l}\rightarrow \\
(2)\end{array}$ & MP & 0.491 & 0.417 & 0.205 \\
\hline 3 & $\mathrm{RC}$ & $\overrightarrow{(1)}$ & SNA & $\overrightarrow{(2)}$ & MP & 0.344 & 0.417 & 0.143 \\
\hline
\end{tabular}

The role of synergized network asset can also be found through a chi-square difference test. The level of significance of the mediator variable can be acquired through a difference test between the partial mediation and full mediation models. Both of the models involve market dynamic adaptability as the mediator variable (Table 5). The partial mediation model links market dynamic adaptability, synergized network asset, and marketing performance in a series relationship (model 1 ), while the full mediation model links them in a triangular relationship (model 2). The difference between chi-square and $\mathrm{df}$ on both models has a level of significance at $\mathrm{p}=0.001$ (This value could be found at the chi-square table at chi-square $=10.8$ and $\mathrm{df}=1$ ). A value of $\mathrm{p}=0.001$ below $5 \%$ indicates that there is no significant difference between the two models. This test strengthens the result of the pathway analysis, namely that synergized network asset does not have the capability to play a mediation role.

Table 5: Mediation Significance Test

\begin{tabular}{|c|c|c|c|c|c|c|}
\hline \multirow[t]{2}{*}{ Mediation model } & \multicolumn{3}{|c|}{ Standardized regression } & \multirow{2}{*}{$\begin{array}{l}\text { Chi- } \\
\text { square }\end{array}$} & \multirow[t]{2}{*}{ df } & \multirow{2}{*}{$\begin{array}{c}\mathbf{p} \\
\text { value }\end{array}$} \\
\hline & MDA $\rightarrow$ SNA & SNA $\rightarrow$ MP & MDA $\rightarrow$ MP & & & \\
\hline $\begin{array}{l}\text { Model } 1 \\
\text { MDA } \rightarrow \text { SNA } \rightarrow \text { MP }\end{array}$ & 0.417 & 0.740 & & 239.7 & 34 & 0.000 \\
\hline $\begin{array}{l}\text { Model } 2 \\
\text { MDA } \rightarrow \text { SNA } \rightarrow \text { MP }\end{array}$ & 0.344 & 0.419 & 0.384 & 228.9 & 33 & 0.000 \\
\hline Difference of chi-s & are and df & & & 10.8 & 1 & 0,001 \\
\hline
\end{tabular}




\section{DISCUSSION}

This research model is able to describe the stages of cooperative behaviour between furniture makers and buyers in achieving marketing performance. This model explains that in order to establish marketing cooperation, companies should equip themselves with two independent variables related to awareness of the external business environment, namely relational capability and market dynamic adaptability. Companies also need to improve quality of cooperation with a mediation variable, namely synergized network asset, which requires willingness to collaborate with their competitive assets and become more long-term oriented.

The important role of relational capability in developing marketing networks shows that the success of furniture companies not only depends on their skill to create the products needed by the consumer but also their ability to form sympathetic and continuous relationships with their partners. Thus, furniture companies can improve their relationship capability by developing a better understanding of the furniture retailers' choices of quality, design, and prices for various kind of products. Furniture companies also need to learn proper communication techniques so that they can convince their customers about the company's superiority (Brennan et al., 2003; Canning \& Hanmer-Lloyd, 2001). Over time, companies can strengthen their bonds with customers through various business or social approaches that will give rise to an attitude of interdependent understanding and support in their business.

Companies should complement their existing business skills with other business development powers, in addition to relational capability, in an endeavor to understand and adopt market dynamic. This dynamic capability should be well controlled as a consequence of strategic activities in order to achieve the objectives of the organization. Market literacy can also be improved by sharing experiences with business partners or undertaking educational training. One of the sharing abilities that a company should master is to understand the market dynamic, which means the company should know how to identify the tendency of market development, especially in furniture design, and adapt flexibly to any changes in the retailers' demands (Liu et al., 2013; Smirnova et al., 2011). Moreover, companies should view customer complaints as suggestions to improve their product quality and services more effectively. This is needed in order to improve customer satisfaction.

The high validity of the research model provides a clear understanding of the role of the new intervening variable, namely synergized network asset. Furniture makers can develop joint marketing synergies with furniture showrooms through problem solving based on win-win solutions that consider the interests of both parties. Furniture makers can also develop marketing strategies that emphasize sustainability of long-term relationships. When the market is unstable and presents difficulties in the supply of furniture, furniture makers should avoid suddenly raising their product prices, and instead choose to delay any price increases in order to maintain the commitment of the price agreed with the customer. They should try to meet the needs of their customers with regard to product quality, on-time delivery, and return of rejected goods. Furniture makers can develop interactive cooperation that is based on openness, integrity, and mutual support of the excellence of business partners (Nielson, 1998).

Synergized network asset has a role to play as a mediation variable but the impact of its role is not as great as that of other variables in achieving marketing performance. Synergized network asset 
is proven to have the ability to bridge relations between variables of cause and effect. Nevertheless, the level of marketing performance obtained by activating the synergized network asset variable is not as great as the direct effect obtained from the market dynamic adaptability variable. The phenomenon in which synergized network plays a less than optimal role shows that the majority of furniture makers prefer a responsive rather than synergistic type of cooperation (Roda et al., 2007). Cooperation on a responsive level requires proper management of internal resources in order to meet the needs of business partners. Cooperation on a synergistic level, meanwhile, not only provides the products needed by business partners but also involves joint resources which require greater commitment, cost, and sacrifice in order to achieve common goals (Setiawan \& Hanfan, 2017).

Synergized network asset makes a contribution to the enhancement of network theory. Previous concepts emphasize the importance of maintaining synergic relationships between companies. Although synergy within the context of relationship marketing has been discussed in the context of mutualistic relationships, the concept has not explained the involvement of more complex parties (Ensign, 1998). In addition, existing concepts have not explored the power of sensitive response that is required for elaborating a network (Connell \& Voola, 2007). Synergized network asset is able to assert the importance of the synergistic nature of networks that is essential for speeding up evaluation, analyzing, and making decisions about business choices (Lado et al., 2011; Tsanos et al., 2014).

\section{CONCLUSION}

This research model is able to describe the stages of cooperative behaviour between furniture makers and buyers in achieving marketing performance. This model explains that in order to establish marketing cooperation, companies should equip themselves with two independent variables related to awareness of the external business environment, namely relational capability and market dynamic adaptability. Companies also need to improve quality of cooperation with a mediation variable, namely synergized network asset, which requires willingness to collaborate with their competitive assets and become more long-term oriented.

Furniture companies have three alternative ways for improving marketing performance. First, they should build relational capability with their partners and then they develop synergized network asset to increase marketing performance. Second, they may also activate market dynamic capability first, and subsequently increase synergized network asset to improve marketing performance. Third, furniture companies can empower market dynamic capability optimally to achieve marketing performance directly. Although any of these three strategies may be implemented, the third has a more significant impact than the others. Companies can fulfil the needs of their business partners by producing goods that consumers really need (Setiawan \& Hanfan, 2017).

The role of synergized network asset as a mediation variable has not yet shown a significant effect. This is not to say that synergized network asset does not have a mediation role but rather that its function in sealing cooperation will be more apparent in businesses that experience rapid growth and require the collaboration of two parties. In industries with slow growth like the furniture industry, more practical cooperation is needed, such as a guarantee to supply products that meet market demand. In addition, the relatively loose relationship between furniture makers and buyers, 
in which both parties are not only able to choose who they wish to partner with but also to break ties in an instant, tends to lack the strength to maintain a commitment that is long-term oriented.

The phenomenon in which synergized network plays a less than optimal role shows that the majority of furniture makers prefer a responsive rather than synergistic type of cooperation. Cooperation on a responsive level requires proper management of internal resources in order to meet the needs of business partners. Cooperation on a synergistic level, meanwhile, not only provides the products needed by business partners but also involves joint resources which require greater commitment, cost, and sacrifice in order to achieve common goals.

Synergized network asset contributes to the development of a concept of networking. Companies should optimize their internal resources in order to improve cooperation and make breakthroughs in their collaborations. Intensification of the concept of synergized network needs to be standardized on a conceptual level so as to become a special topic to complement studies on mutual relationship, collaboration, and network.

\section{MANAGERIAL IMPLICATION AND FUTURE RESEARCH}

The quality of communication with customers can be enhanced through regular site visits to business partners. The ability of furniture makers to understand the needs and desires of customers plays an important role in establishing business relationships. Although these efforts can be made through remote contact, such as by telephone, the makers will have a greater emotional impact if the communication takes place face to face. Problems that arise with difficult customers can be expressed and resolved through direct communication. Furniture makers can manage their sales employees by making regular visits to furniture showrooms in the guise of a customer.

Furniture makers can assure customers of their competence by providing a display space or room for their own products and use of the company's website. The display will show the different types of furniture that can be manufactured by the company while the website can inform customers who live far away from the company about the availability of furniture. The website also serves as a media campaign to attract new customers.

Media for information sharing and cooperation, such as business meetings for furniture makers, should be initiated by shelter agencies such as the Indonesian Furniture and Handicraft Industry Association (ASMINDO), as well as government institutions such as the State Ministry for Cooperatives and Small Medium Enterprises (Kemenkop UKM) and the Ministry of Industry. Through business meetings, information can be shared about changes in government policy, shifts in furniture design, and market developments. Furniture makers can ask the government to encourage furniture growth by providing low-interest loans, production training, and marketing assistance.

The respondents were interviewed to obtain a high level of validity in their answers to the research questioners. In order to obtain data normality, the number of research respondents, which was initially 420 furniture makers, was reduced to 280 respondents, through a screening test, trimming test, and Mahalanobis distance analysis. Respondents who gave incomplete and inconsistent answers were eliminated. Therefore, the method of interviewing respondents was able to reduce differences in perception and ensure that the questionnaire was completed properly. 
There are a number of empirical connections between the antecedent variables and other variables that have not yet been explored. Further research is recommended to discover more information about the relationships between antecedent variables, such as the relationship between relational capability and market dynamic adaptability. Some of the facts obtained show that intensive activities to enhance relationships with partners improve the furniture makers' level of adaptation. This step is also required to improve the goodness of fit of the research model so that the model reflects the actual empirical conditions.

\section{REFERENCES}

Ambrose, E., Marshall, D., \& Lynch, D. (2010). Buyer supplier perspectives on supply chain relationships. International Journal of Operations \& Production Management, 30(12), 1269-1290.

An, X., Deng, H., Chao, L., \& Bai, W. (2014). Knowledge management in supporting collaborative innovation community capacity building. Journal of Knowledge Management, 18(3), 574590.

Baker, W., \& Sinkula, J. (1999). The synergistic effect of market orientation and learning orientation on organizational performance. Academy of Marketing Science, 27(4), 411-427.

Batonda, G., \& Perry, C. (2003). Approaches to relationship development processes in inter-firm networks. European Journal of Marketing, 37(10), 1457-1484.

Brennan, D. R., Turnbull, P. W., \& Wilson, D. I. (2003). Dyadic adaptation in business-to-business markets. European Journal of Marketing, 37(11/12), 1636-1655.

Brown, J. R., Weaven, S. K., Dant, R. P., \& Crosno, J. L. (2016). Boosting the effectiveness of channel governance options The moderationing role of relational norms. European Journal of Marketing, 50(1-2), 29-57.

Burt, R. S. (1992). Structural holes : the social structure of competition. MA : Harvard University Press.

Canning, L., \& Hanmer-Lloyd, S. (2001). Managing the environmental adaptation process in supplier-customer relationships. Business Strategy and the Environment, 10(4), 225-237.

Cheng, J.-H., Chen, M.-C., \& Huang, C.-Mi. (2014). Assessing inter-organizational innovation performance through relational governance. Supply Chain Management: An International Journal, 19(2), 173-186.

Claro, D. P., \& Claro, P. B. de O. (2011). Networking and developing collaborative relationships: evidence of the auto-part industry of Brazil. Journal of Business \& Industrial Marketing, 26(7), 514-523.

Connell, J., \& Voola, R. (2007). Strategic alliances and knowledge sharing: synergies or silos? Journal of Knowledge Management, 11(3), 52-66.

Corsten, D., \& Felde, J. (2005). Exploring the performance effects of key-supplier collaboration: An empirical investigation into Swiss buyer-supplier relationship. International Journal of Physical Distribution \& Logistics Management, 35(6), 445-461.

Department of Trade and SMEs Industries. (2017). Development of Furniture Industry in Central Java Province. Government of Central Java Province: Indonesia.

Eiriz, V., \& Wilson, D. (2004). Research in relationship marketing antecedents, traditions and integration. European Journal of Marketing, 40(3/4), 275-291.

Ensign, P. C. (1998). Interrelationships and horizontal strategy to achieve synergy and competitive advantage in the diversified firm. Management Decision, 36(10), 657-668. 
Ferdinand, A. T., \& Killa, M. F. (2018). The pareto sales network asset: A networked power perspective. Business: Theory and Practice, 19, 103-113.

Fierro, J. C., Florin, J., Perez, L., \& Whitelock, J. (2011). Inter-firm market orientation as antecedent of knowledge transfer, innovation and value creation in networks. Management Decision, 49(49), 444-467.

Fynes, B., \& Voss, C. (2002). The moderating effect of buyer-supplier relationships on quality practices and performance. International Journal of Operations \& Production Management, 22(6), 589-613.

Gronroos, C. (1994). From marketing mix to relationship marketing. Journal of Management Decision, 32(5), 4-20.

Hallen, L., Johanson, J., \& Mohamed, N. S. (1991). Interfirm Adaptation in Business Relationships. Journal of Marketing, 55(2), 29-37.

Hartono, R. D. S. (2013). Study role of the solutive harmonize collaboration in channel distribution and it's impact to bussiness relationship performance (Unpublished Doctoral Dissertation) Diponegoro University Indonesia.

Izquierdo, C. C., \& Cillian, J. G. (2004). The interaction of dependence and trust in long-term industrial relationships. European Journal of Marketing, 38(8), 974-994.

Jambulingam, T., Kathuria, R., \& Nevin, J. R. (2011). Fairness-trust-loyalty relationship under varying conditions of supplier-buyer interdependence. Journal of Marketing Theory and Practice, 19(1), 39-56.

Jones, S. C., Knotts, T. L., \& Udell, G. G. (2008). Market orientation for small manufacturing suppliers The importance of product-related factors. Journal of Business \& Industrial Marketing, 23(7), 443-453.

Krackhardt, D. (1993). Network and organization : structure, form and action. Harvard Business School Press.

Kracklauer, A., Passenheim, O., \& Seifert, D. (2001). Mutual customer approach: how industry and trade are executing collaborative customer relationship management. International Journal of Retail \& Distribution Management, 29(12), 515-519.

Lado, A. A. L., Paulraj, A., \& Chen, I. J. (2011). Customer focus, supply-chain relational capabilities and performance: evidence from US manufacturing industries. The International Journal of Logistics Management, 22(2), 202-221.

Landeros, R., Reck, R., \& Plank, R. E. (1995). Maintaining buyer-supplier partnerships. International Journal of Purchasing and Materials Management, 31(3), 2-12.

Lin, C.-P., Tsai, Y. H., \& Chiu, C.-K. (2009). Modeling customer loyalty from an integrative perspective of self-determination theory and expectation-confirmation theory. Journal of Business and Psychology, 24(3), 315-326.

Lin, K.-H., Huang, K.-F., \& Peng, Y.-P. (2014). Impact of export market orientation on export performance: A relational perspective. Baltic Journal of Management, 9(4), 403-425.

Ling-yee, L., \& Ogunmokun, G. O. (2001). The influence of interfirm relational capabilities on export advantage and performance: an ampirical analysis. International Business Review, 10, 399-420.

Liu, H., Ke, W., Wei, K. K., \& Hua, Z. (2013). Effects of supply chain integration and market orientation on firm performance. International Journal of Operations \& Production Management, 33(3), 322-346.

McDowell, W., \& Harris, M. L. (2009). Relational orientation and performance in micro business and small and medium-sized enterprises: An examination of interorganization telationships". Journal of Business and Enterpreneurship, 21(2), 1-19. 
Mention, A.-L. (2013). Intelectual capital and performance with the banking sector of Luxembourg and Belgium. Journal of Intelectual Capital, 14(2), 286-309.

Morgan, R. M., \& Hunt, S. D. (1994). The commitment-trust theory of relationship marketing. Jurnal of Marketing, 58(3), 20-38.

Morgan, T., Anokhin, S., \& Wincent, J. (2016). Entrepreneurial orientation, firm market power and opportunism in networks. Journal of Business \& Industrial Marketing, 31(1), 99-111.

Nabhan, F. (2012). Developing the dynamic collaboration capability and its impact to business performance (Unpublished doctoral dissertation). Diponegoro University Indonesia.

Ngungi, I. K., Johnsen, R. E., \& Erdelyi, P. (2010). Relational capabilities for value co-creation and innovation in SMEs. Journal of Small Business and Enterprise Development, 17(2), 260-278.

Nielson, C. C. (1998). An empirical examination of the role of "closeness" in industrial buyerseller relationships. European Journal of Marketing, 32(5/6), 441-463.

Nupus, H., \& Ichwanudin, W. (2020). Integrated paradigm of lean supply chain of SMEs by utilizing customer relationship management capabilities and family distribution networks. International Journal of Supply Chain Management, 9(2), 93-103.

Nurcholis, L. (2012). Developing concept of equilateral relationship to improve supply chain performance through quality of synergy, adaptation and low cost leadership. (Unpublished doctoral dissertation). Diponegoro University Indonesia.

Prior, D. D. (2012). The effects of buyer-supplier relationships on buyer competitiveness. Journal of Business \& Industrial Marketing, 27(2), 100-114.

Roda, J.-M., Cadène, P., Guizol, P., Santoso, L., \& Fauzan, A. U. (2007). Atlas of furniture industry in Jepara, Indonesia. French Agricultural Research Centre for International Development and Center for International Forestry Research.

Santra, I. K. (2018). Entrepreneurial orientation and marketing performance of budget hotel SMES in Bali island. International Journal of Entrepreneurship, 22(4), 1-11.

Setiawan, A. I., \& Hanfan, A. (2017). Elaborating the role of network synergy capacity as a supplier's alternative terminal for achieving marketing performance. International Journal of Business and Society, 18(2), 245-262.

Statistics of Indonesia. (2017). Demand for Local Commodities in Central Java Province. https://www.bps.go.id/

Siguaw, J. A., Simpton, P. M., \& Baker, T. L. (1998). Effects of supplier market orientation on distributor market orientation and the channel relationship: the distributor perspective. Journal of Marketing, 62(3), 99-111.

Smirnova, M., Naudé, P., Henneberg, S. C., Mouzas, S., \& Kouchtch, S. P. (2011). The impact of market orientation on the development of relational capabilities and performance outcomes: The case of Russian industrial firms. Industrial Marketing Management, 40(1), 44-53.

Stevenson, G. (2001). Re-evaluating the marketing concept. European Business Review, 13(2), 95100.

Teece, D. J., Pisano, G., \& Shuen, A. (1997). Dynamic capabilities and strategic management. Strategic Management Journal, 18(7), 509-533.

Tsanos, C. S., Zografos, K. G., \& Harrison, A. (2014). Developing a conceptual model for examining the supply chain relationships between behavioural antecedents of collaboration, integration and performance. The International Journal of Logistics Management, 25(3), 418-462.

Turner, G. B., LeMay, S. A., Hartley, M., \& Wood, C. M. (2000). Interdependence and cooperation in industrial buyer-supplier relationships. Journal of Marketing Theory and Practice, 8(8), 
$16-24$.

Welbourne, T. M., \& Val, M. P. d. (2009). Relational capital strategic advantage for small and medium - size entreprise through negotiation and collaboration. Springer Sciece and Business Media B.V., 18, 483-497.

Westerlund, M., \& Rajala, R. (2010). Learning and innovation in inter-organizational network collaboration. Journal of Business \& Industrial Marketing, 25(6), 435-442. 
Appendix 1: Items of questionnaire

Synergized network asset

1. The company places its own needs together with the retailer in solving problems

2 . The company stresses the sustainability of the business relationship with the retailer

3 . The company guarantees the availability of product supply to the retailer

4. The company is committed to forging mutual bonds with the retailer

Relational capability

1. The company has a deep understanding of the retailer's characteristics

2. The company is able to convince the retailer of the benefits of the relationship

3. The company is able to foster a continuous close relationship with the retailer

Market dynamic adaptability

1. The company always analyzes market trends well

2. The company is quick to resolve retailers' complaints

3. The company is able to adjust to market changes comprehensively

Marketing performance

1. The sales value of the company has increased in the last three years

2. The sales volume of the company has experienced significant growth in the last three years

3. The company has experienced additional sales growth in the last three years 